\title{
Pengaruh Konsentrasi Gel Lidah Buaya dan Lama Pencelupan terhadap Kualitas Buah Tomat (Lycopersicum esculentum Mill.)
}

\author{
Effect of Aloe Vera Gel Concentration and Immersion Time on Tomato \\ Fruit Quality (Lycopersicum esculentum Mill.) \\ Eviliany Pinayungan', Syamsuddin ${ }^{1}$, Rita Hayati ${ }^{1}$ \\ ${ }^{1}$ Program Studi Agroteknologi PSDKU Gayo Lues, Fakultas Pertanian, \\ Universitas Syiah Kuala \\ evilianypinayungan@gmail.com
}

\begin{abstract}
Abstrak. Penelitian ini memiliki tujuan untuk mengetahui pengaruh konsentrasi gel lidah buaya dan lama pencelupan serta interaksi antara kedua faktor terhadap kualitas buah tomat, yang dilakukan di Laboratorium Ilmu dan Teknologi Benih Program Studi Agroteknologi Fakultas Pertanian Universitas Syiah Kuala, berlangsung pada bulan Oktober 2020 hingga Februari 2021. Rancangan penelitian yang digunakan adalah Rancangan Acak Kelompok pola Faktorial 4 x 3 dengan 3 ulangan. Faktor yang diteliti yaitu konsentrasi gel lidah buaya terdiri dari 4 taraf yaitu tanpa konsentrasi gel lidah buaya, 15, 30, 45\% serta lama pencelupan terdiri dari 3 taraf yaitu 30, 60 dan 90 detik. Hasil penelitian menunjukkan bahwa konsentrasi gel lidah buaya berpengaruh nyata terhadap organoleptik warna, berpengaruh tidak nyata terhadap susut bobot, kadar air, vitamin $\mathrm{C}$, warna dan organoleptik tekstur, aroma dan rasa. Kualitas buah tomat terbaik dijumpai pada konsentrasi gel lidah buaya $45 \%$. Perlakuan lama pencelupan terhadap kualitas buah tomat terbaik cenderung dijumpai pada perlakuan lama pencelupan 90 detik, walaupun berbeda tidak nyata dengan perlakuan lama pencelupan 30 dan 60 detik. Terdapat interaksi yang tidak nyata antara gel lidah buaya dan lama pencelupan terhadap kualitas buah tomat.
\end{abstract}

Kata kunci : Konsentrasi gel lidah buaya, lama pencelupan dan buah tomat

\begin{abstract}
Abstrat. This study aims to determine the effect of aloe vera gel concentration and immersion time as well the interaction between the two on the quality of tomato fruit. The research was carried out at the Seed Science and Technology Laboratory of the Agrotechnology Study Program, Faculty of Agriculture, Syiah Kuala University, taking place from October 2020 to February 2021. The research design used was a $4 \times 3$ factorial randomized block design with 3 replications. The factors studied were the concentration of aloe vera gel consisting of 4 levels, namely without concentration of aloe vera gel, 15, 30, 45\% and the immersion time consisted of 3 levels, namely 30,60 and 90 seconds. The results showed that the concentration of aloe vera gel had a significant effect on organoleptic color, but had no significant effect on weight loss, moisture contect, vitamin $\mathrm{C}$, color and organoleptic texture, scent and taste. The best quality of tomatoes was found at a concentration of $45 \%$ aloe vera gel. The duration of the immersion treatment on the quality of the best tomatoes tended to be found in the treatment of 90 second immersion, although not significantly different from the treatment of 30 and 60 second immersion. There was not significant interaction between aloe vera gel concentration and immersion time on the quality of tomatoes.
\end{abstract}

Key words : Aloe vera gel concentration, immersion time and tomatoes

\section{PENDAHULUAN}

Tomat adalah jenis buah yang sangat disukai masyarakat, memiliki banyak sekali kandungan gizi untuk kesehatan tubuh. Kandungan gizi pada buah tomat yaitu vitamin $C$ dan mineral yang cukup tinggi (Sulistyowati et al., 2019). Mineral lain yang terdapat pada buah tomat yaitu vitamin A, vitamin $\mathrm{K}$, vitamin $\mathrm{E}$, kalium, magnesium, besi, phosphor dan protein (Mateljen, 2007). Pemanfaatan buah 
tomat adalah sebagai sayur, bumbu masak, bahan pewarna makanan dan bahan komestik. Selain itu tomat juga dimanfaatkan untuk bahan industri seperti saus dan sari buah (Drakel, 2011).

Badan Pusat Statistik (2019) kapasitas produksi tomat di Indonesia tahun 2016 sebanyak 15,31 ton ha-1, tahun 2017 sebanyak 17,31 ton ha ${ }^{-1}$, tahun 2018 sebanyak 18,04 ton ha ${ }^{-1}$ dan pada tahun 2019 meningkat sebanyak 18,63 ton ha ${ }^{-1}$, dari data yang tertera dapat menunjukkan bahwa terjadi peningkatan produktivitas tomat di Indonesia setiap tahunnya, tetapi kebutuhan masyarakat akan tomat juga semakin meningkat dengan bertambahnya jumlah penduduk. Tomat mengandung banyak air, sehingga sensitif pada kerusakan dan pembusukan. Sebagian faktor yang dapat mempengaruhi pembusukan tomat ialah fisiologis dan mikrobiologis, keduanya berpengaruh besar terhadap mutu dari buah tomat. Adapun gejala yang ditimbulkan yaitu pertukaran bentuk fisik menjadi lunak dan tekstur yang terlihat kerut (Sulistyowati et al., 2019).

Edible coating adalah salah satu metode yang bisa dipakai pada perpanjangan masa simpan serta mempertahankan kualitas buah serta sayur di temperatur ruang (Pantastico, 2003). Edible coating yakni susunan tipis yang bisa dikonsumsi digunakan untuk makanan dengan metode membungkus, mencelupkan, menyikat atau menyemprot untuk memberikan penambahan selektif pada pergerakan gas, kelembaban, zat terlarut serta melindungi kerusakan fisik (Marwina et al.,2016).

Salah satu bahan dasar untuk pembuatan edible coating yaitu gel lidah buaya. Gel lidah buaya adalah susunan bening yang didapat dari sel parenkim daun lidah buaya segar. Kandungan dalam gel lidah buaya yaitu antraquinon (aloin, barbaloin, emodin), polisakarida (selulosa, manosa, glukomanan), vitamin (B1, B2, B6, C) dan enzim (amilase, katalase, lipase). Kandungan enzim pada lidah buaya untuk digunakan sebagai antioksidan dalam meningkatkan masa simpan bahan (Toro et al., 2017). Edible coating dengan bahan dasar polisakarida dimanfaatkan terkhusus untuk buah dan sayur, dikarenakan mempunyai kemampuan untuk bertindak sebagai membran permable selektif untuk pergantian gas dioksida dengan oksigen (Budiman, 2011).

Hasil penelitian Marwina et al. (2016) menunujukkan bahwa hasil terbaik buah tomat pada konsentrasi gel lidah buaya 30\% disimpan dalam kulkas dengan temperatur $10^{\circ} \mathrm{C}$ masih disukai oleh panelis sampai hari ke - 21. Penyimpanan terbaik sampai hari ke-12 pada analisis susut bobot terdapat pada perlakuan konsentrasi gel lidah buaya $30 \%$ yang disimpan dengan temperatur $10{ }^{\circ} \mathrm{C}$ nilai $15,52 \%$, pada analisis persentase tingkat kekerasan terbaik pada konsentrasi $30 \%$ pada temperatur rendah $10^{\circ} \mathrm{C}$ dengan nilai $1.357 \mathrm{~kg}$ serta kandungan vitamin $\mathrm{C}$ terbaik terdapat pada konsentrasi $30 \%$ pada temperatur rendah $10^{\circ} \mathrm{C}$ nilai $1,42 \mathrm{mg}$ $50 \mathrm{~g} \mathrm{~g}^{-1}$. Menurut hasil penelitian Garcia et al. (2013) melapisi buah tomat dengan gel lidah buaya dapat menjaga kekenyalan dan menunda pematangan, tetapi tidak dapat mencegah penurunan berat buah selama penyimpanan pada temperatur 22 ${ }^{\circ} \mathrm{C}$.

Salah satu cara yang dapat dipakai pada pengemasan dengan edible coating ialah pencelupan. Lama pencelupan dapat mempengaruhi lapisan yang dihasilkan. Smakin lama pencelupan maka semakin tebal lapisan yang terbentuk sehingga dapat menurunkan laju metabolisme. Hasil penelitian Hasanah (2009) 
menunjukkan bahwa pada perlakuan lama pencelupan paprika selama 60 detik dalam gel lidah buaya dengan konsentrasi CMC 1\% memiliki penurunan susut bobot dan nilai kekerasan terkecil dan dapat memperlama masa simpan hingga 21 hari. Yudiana (2013) menyatakan lama pencelupan kedalam gel lidah buaya berpengaruh sangat nyata terhadap umur simpan buah anggur yang dilihat dari peubah susut bobot, kandungan vitamin C, warna serta uji organoleptik. Mempengaruhi nyata pada KA dan berdampak tidak nyata pada uji organoleptik tekstur serta rasa. Perlakuan masa perendaman dalam gel lidah buaya terbaik ditemukan pada lama pencelupan 90 detik. Tujuan dari penelitian ini untuk mengetahui pengaruh konsentrasi gel lidah buaya dan lama pencelupan serta interaksi antara kedua faktor tersebut terhadap kualitas buah tomat.

\section{Tempat dan Waktu Penelitian}

\section{METODE PENELITIAN}

Penelitian ini dilaksanakan di Laboratorium Ilmu dan Teknologi Benih, Fakultas Pertanian, Universitas Syiah Kuala, Darussalam, Banda Aceh yang dimulai dari bulan September 2020 sampai Februari 2021.

\section{Alat dan Bahan Penelitian}

Alat-alat yang dipakai selama penelitian yaitu timbangan analitik, sendok pengaduk, oven, blender, lemari pendingin, kertas saring, beaker glass $1000 \mathrm{ml}$, Erlenmeyer $100 \mathrm{ml}$, pipet tetes, gelas ukur, baskom plastik, pisau, mortar, pestle, cawan alumunium, stopwatch, alat titrasi. Bahan-bahan yang dipakai selama penelitian yaitu buah tomat varietas servo $\mathrm{F} 1$ sebanyak $7 \mathrm{~kg}$, lidah buaya varietas Pontianak sebanyak $8 \mathrm{~kg}$, aquades (9,6 Liter), asam sitrat 10\% (200 gram), betadine $(70 \mathrm{ml})$ dan amilum sebanyak 2 gram.

\section{Rancangan Percobaan}

Penelitian ini menggunakan Rancangan Acak Kelompok (RAK) pola faktorial 4x3 dengan 3 ulangan terdapat 12 kombinasi perlakuan serta 36 unit percobaan. Faktor yang diteliti adalah konsentrasi gel lidah buaya dan lama pencelupan. Faktor konsentrasi gel lidah buaya $(\mathrm{G})$ terdiri dari 4 taraf yaitu : $\mathrm{G}_{0}=$ $0 \%, \mathrm{G}_{1}=15 \%, \mathrm{G}_{2}=30 \%, \mathrm{G}_{3}=45 \%$. Faktor lama pencelupan (P) terdiri atas 3 taraf yaitu : $\mathrm{P}_{1}=30$ detik, $\mathrm{P}_{2}=60$ detik dan $\mathrm{P}_{3}=90$ detik.

\section{Pelaksanaan Penelitian}

a. Pembuatan Gel Lidah Buaya

Pada tahapan ini akan dimodifikasi dalam teknik pembuatan gel lidah buaya dengan sifat coating yang baik, tahapan yang akan dilakukan yaitu:

- Sortasi dan pencucian daun tanaman lidah buaya

Pada tahap ini dilakukan pemilihan daun tanaman lidah buaya yang dapat dilihat dari tingkat kematangan. Daun tanaman lidah buaya yang digunakan berwarna hijau, panjang $30-50 \mathrm{~cm}$, lebar $5-8 \mathrm{~cm}$, ketebalan $2-3 \mathrm{~cm}$, tidak cacat fisik, patah ataupun terdapat bercak penyakit dan berumur sekitar 8 bulan . Lidah buaya diambil dari 1 tanaman yang berasal dari toko bunga Kiky Garden Gampong Limpok dengan varietas Pontianak. Setelah disortasi kemudian dicuci 
menggunakan air mengalir agar meghilangkan kotoran permukan daun lidah buaya

- Perendaman

Daun tanaman lidah buaya yang telah dibersihkan kemudian dilakukan peredaman selama 30 menit dalam larutan asam sitrat yang bertujuan untuk mengurangi infeksi dari mikroba pada bagian permukaan daun.

- Pemisahan bagian kulit lidah buaya

Pada tahapan ini dilakukan pemisahan bagian-bagian kulit aloe vera buaya dengan cara tanamana dikupas memakai pisau, sehingga hanya tertinggal daging dari tanaman lidah buaya.

- Pencucian

Pada bagian daging daun tanaman lidah buaya ini terdapat bagian getah kuning (yellow sap). Yellow sap ini dapat mengakibatkan gel berwarna kuning, berbau tidak sedap, sehingga perlu dihilangkan. Cara untuk menghilangkan Yellow sap dapat dilakukan pencucian menggunakan air hangat dengan suhu sekitar $36-37^{\circ} \mathrm{C}$.

- Penghancuran dan penyaringan

Daging daun lidah buaya kemudian dihaluskan menggunakan blender selama 1 menit, proses penghancuran dilakukan tidak terlalu lama karena dapat mengakibatkan terjadinya reaksi pencoklatan enzimatis dalam gel. Setelah itu gel lidah buaya disaring dengan menggunakan saringan dan dimasukkan dalam Erlenmeyer $1000 \mathrm{ml}$.

b. Aplikasi Konsentrasi Gel Lidah Buaya dan Lama Pencelupan pada Buah Tomat

Teknik pengaplikasian konsentrasi gel lidah buaya untuk buah tomat dilaksanakan dengan cara pencelupan. Gel yang diaplikasikan ialah gel lidah buaya yang baru diolah karena merupakan gel terbaik untuk coating (Lestari, 2008). Buah tomat yang digunakan varietas hibrida servo F1, berwarna kuning kemerahan masak fisiologis sekitar $60-80 \%$. Tomat terlebih dahulu dibersihkan menggunakan air mengalir lalu ditiriskan selama 10 menit. Gel lidah buaya disiapkan sesuai dengan konsentrasi perlakukan yaitu $\mathrm{G}_{0}=(1000 \mathrm{ml}$ aquades $) \mathrm{G}_{1}$ $=15 \%$ (150 ml gel lidah buaya dan $850 \mathrm{ml}$ aquades $), \mathrm{G}_{2}=30 \%$ (300 $\mathrm{ml}$ gel lidah buaya dan $700 \mathrm{ml}$ aquades) dan $\mathrm{G}_{3}=45 \%$ (450 ml gel lidah buaya dan $550 \mathrm{ml}$ aquades). Kemudian tomat dicelupkan ke dalam larutan coating dengan rentang waktu sesuai dengan perlakuan yaitu $\mathrm{P}_{1}=30$ detik, $\mathrm{P}_{2}=60$ detik dan $\mathrm{P}_{3}=90$ detik. Setelah pencelupan buah tomat ditiriskan selama kurang lebih 20 menit pada suhu ruang dan selanjutnya tomat dimasukkan kedalam plastik klip dan disimpan kedalam kulkas dengan suhu $10^{\circ} \mathrm{C}$ selama 12 hari.

\section{Pengujian Kualitas Tomat}

- Susut Bobot

Pengmatan ini dilakukan dengan cara menimbang bobot sebelum pengaplikasian gel lidah buaya dan bobot akhir setelah pengaplikasian gel lidah 
buaya yang telah disimpan selama 12 hari dengan memakai timbangan. Pengukuran perubahan berat digunakan 3 buah tiap perlakuan dan dihitung pada unit persentase perubahan berat setelah penyimpanan serta dihitung dengan menggunakan rumus:

$$
\text { Susut bobot }=\underline{\text { Berat awal }- \text { berat akhir }} \times 100 \%
$$

\section{Berat awal}

\section{- Kadar Air}

Pengujian kadar air dilakukan sebelum dan sesudah pada setiap perlakuan. Cara pengujian kadar air yang sering dipakai untuk produk pangan ialah cara pengeringan atau metode oven (Air Oven Method). Pada metode ini sampel tomat dihaluskan dalam mortar dengan pestle, lalu sampel ditimbang 5 gram dengan memakai timbangan analitik, lalu dimasukkan kedalam cawan alumunium. Selanjutnya sampel beserta cawan dikeringkan dalam oven selama 3 jam pada suhu $105^{\circ} \mathrm{C}$ dan didinginkan selama 15 menit. Kemudian sampel ditimbang dengan timbangan analitik. Rumus uji kadar air:

$$
\text { Kadar air }=\frac{b-c}{b-a} \times 100 \%
$$

Keterangan: a : Berat wadah (cawan (gram))

$\mathrm{b}:$ Berat wadah + berat sampel awal (sebelum diovenkan)

c : Berat wadah + berat sampel akhir (setelah diovenkan)

- Uji Kadar Vitamin C

Penentuan titrasi vitamin $\mathrm{C}$ dapat dilakuan dengan melumatkan tomat dan ditimbang sebanyak 5 gram untuk setiap perlakuan. Kemudian diencerkan dengan aquades sampai menjadi $100 \mathrm{ml}$, lalu disaring menggunakan kertas saring sehingga mendapatkan filtrat yang akan diambil sebanyak $10 \mathrm{ml}$. Selanjutnya dititrasi menggunakan betadine (larutan amilum iodine) sampai berubah warna menjadi kuning kecoklatan. Catat jumlah ml iodine yang dipakai, selanjutnya hasilnya dimasukkan kedalam rumus:

$$
\text { Vitamin } C=\frac{\text { ml Iodin } 0,01 \mathrm{~N} \times 0,88 \times 0,1 \times 100}{\text { berat bahan }}
$$

- Uji Warna

Pengukuran warna dilakukan dengan membandingkan kulit buah tomat dengan menggunakan photoshop. Pengukuran dilakukan sebelum dan sesudah perlakuan. Pengukuran warna pada permukaan buah tomat ditentukan dari data digital dengan tingkat intensitas cahaya merah, hijau dan biru (RGB) yang diambil dengan menggunakan kamera digital. Nilai RGB buah tomat dikonversi menjadi nilai $\mathrm{L}$, a dan $\mathrm{b}$ dengan persamaan berikut:

$$
\begin{aligned}
& \mathrm{L}=25\left[\frac{100 \mathrm{Y}}{\mathrm{Y}_{\mathrm{o}}}\right]^{\frac{1}{3}}-16 \\
& \mathrm{a}=500\left[\left(\frac{\mathrm{X}}{\mathrm{X}_{\mathrm{o}}}\right)^{\frac{1}{3}}-\left(\frac{\mathrm{Y}}{\mathrm{Y}_{\mathrm{o}}}\right)^{\frac{1}{3}}\right]
\end{aligned}
$$




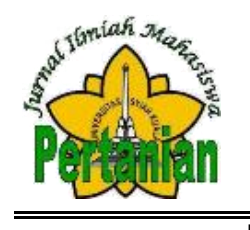

$b=200\left[\left(\frac{Y}{Y_{0}}\right)^{\frac{1}{3}}-\left(\frac{Z}{Z_{0}}\right)^{\frac{1}{3}}\right]$

Dengan nilai $\mathrm{X}_{0}=98,071 ; \mathrm{Y}_{0}=100 ; \mathrm{Z}_{0}=118,225$

- Uji Organoleptik

Uji organoleptik atau uji indra merupakan cara pengujian dengan menggunakan indra manusia sebagai alat utama untuk pengukuran daya penerimaan terhadap produk. Uji organoleptik meliputi warna, tekstur, aroma dan rasa. Uji organoleptik yang akan digunakan yaitu uji hedonic yang dilakukan dengan menggunakan panelis sebagai konsumen dengan tujuan untuk mengetahui tingkat penerimaan konsumen terhadap buah tomat yang telah diberi perlakuan selama penyimpanan, kemudian panelis diminta untuk memberikan tanggapan tentang kesukaan atau tidak kesukaan terhadap bahan yang diberikan. Parameter yang digunakan meliputi: warna, tekstur, aroma dan rasa.

\section{HASIL DAN PEMBAHASAN}

\section{Pengaruh Gel Lidah Buaya terhadap Kualitas Buah Tomat}

Hasil analisis ragam memperlihatkan bahwa konsentrasi gel lidah buaya berdampak nyata pada uji organoleptik warna dan berdampak tidak nyata pada susut bobot, kadar air, kandungan vitamin C, warna pada nilai L (kecerahan), nilai a (merah), nilai b (kuning) serta uji organoleptik tekstur, aroma dan rasa. Rerata kualitas buah tomat akibat perlakuan gel lidah buaya dapat dilihat pada Tabel 1.

Tabe1 1. Rerata kualitas buah tomat akibat perlakuan konsentrasi gel lidah buaya

\begin{tabular}{cccccc}
\hline \multirow{2}{*}{ Peubah } & \multicolumn{4}{c}{ Konsentrasi Gel Lidah Buaya $(\%)$} & \multirow{2}{*}{ BNJ } \\
\cline { 2 - 4 } & $\mathrm{G}_{0}(0)$ & $\mathrm{G}_{1}(15)$ & $\mathrm{G}_{2}(30)$ & $\mathrm{G}_{3}(45)$ & \\
\hline Susut Bobot (\%) & 1,37 & 1,29 & 1,88 & 1,63 & - \\
Kadar Air (\%) & 94,43 & 94,94 & 95,07 & 95,24 & - \\
Vitamin C & 20,34 & 19,86 & 20,37 & 20,23 & - \\
Warna & & & & & \\
L (kecerahan) & 36,96 & 36,40 & 36,29 & 34,29 & - \\
a (merah) & 36,63 & 35,74 & 36,11 & 37,37 & - \\
b (kuning) & 41,37 & 40,92 & 41,63 & 39,66 & - \\
Organoleptik & & & & & \\
Warna & $5,22 \mathrm{ab}$ & $5,00 \mathrm{ab}$ & $4,79 \mathrm{a}$ & $5,78 \mathrm{~b}$ & 0,79 \\
Tekstur & 4,92 & 4,97 & 5,01 & 5,45 & - \\
Aroma & 5,04 & 4,81 & 4,95 & 5,10 & - \\
Rasa & 4,43 & 4,46 & 4,43 & 4,58 & - \\
\hline
\end{tabular}

Keterangan : Angka yang diikuti oleh huruf yang sama berbeda tidak nyata pada taraf 5\% (Uji $\mathrm{BNJ}_{0,05}$ )

Dari hasil penelitian memperlihatkan bahwa mutu buah tomat terbaik ditemukan pada perlakuan konsentrasi gel lidah buaya 45\%. Perihal ini diprediksi semakin tinggi konsentrasi gel lidah buaya yang diberikan bisa mempengaruhi lapisan coating yang tercipta pada buah tomat. Gel lidah buaya bisa diaplikasikan dalam teknologi edible coating, sebab gel tersebut sebagian besar terdiri dari polisakarida. Gel lidah buaya ada sebagian komponen bioaktif yang mampu 
membatasi kehancuran produk pangan baik dalam wujud buah segar ataupun olahan. Acemannan yang ada dalam polisakarida berperan selaku antimikroba serta bisa mengobati cedera jaringan sehingga pemakaian gel lidah buaya bisa mengobati kualitas dan memperpanjang masa simpan tomat (Subagio, 2017).

Berdasarkan hasil penelitian Marwina et al., 2016 mengemukakan bahwa konsentrasi gel aloe vera $30 \%$ berdampak pada analisis susut bobot, persentase kekerasan dan analisis vitamin $\mathrm{C}$ pada penyimpanan tempetarur rendah $10{ }^{\circ} \mathrm{C}$. Menurut Subagio (2017), pemakaian edible coating gel lidah buaya dapat mengurangi kandungan air pada permukaan bahan sehingga kerusakan oleh mikroba dapat dihindari, membetulkan struktur permukaan bahan, kurangi terjadinya kehilangan cairan, kurangi kontak oksigen, sifat asli produk semacam flavor bisa dipertahankan serta memperbaiki penampilan produk.

\section{Pengaruh Lama Pencelupan terhadap Kualitas Buah Tomat}

Hasil analisis ragam memperlihatkan bahwa lama pencelupan kedalam gel lidah buaya berdampak tidak nyata terhadap susut bobot, kadar air, kandungan vitamin C, warna pada nilai L (kecerahan), nilai a (merah), nilai b (kuning) dan uji organoleptik pada warna, tekstur, aroma dan rasa. Rerata kualitas buah tomat akibat perlakuan lama pencelupan bisa dilihat pada Tabel 2 .

Tabel 2. Rerata kualitas buah tomat akibat perlakuan lama pencelupan

\begin{tabular}{cccc}
\hline \multirow{2}{*}{ Peubah } & \multicolumn{3}{c}{ Lama Pencelupan (Detik) } \\
\cline { 2 - 4 } & 30 & 60 & 90 \\
\hline Susut Bobot (\%) & 2,56 & 1,26 & 1,72 \\
Kadar Air (\%) & 94,89 & 95,08 & 94,79 \\
Vitamin C & 20,54 & 19,99 & 20,07 \\
Warna & & & \\
L (kecerahan) & 35,58 & 36,30 & 36,08 \\
a (merah) & 37,36 & 35,78 & 36,25 \\
b (kuning) & 40,30 & 41,14 & 41,25 \\
Organoleptik & & & \\
Warna & 5,29 & 4,87 & 5,43 \\
Tekstur & 5,09 & 5,05 & 5,13 \\
Aroma & 4,99 & 4,89 & 5,05 \\
Rasa & 4,41 & 4,55 & 4,47 \\
\hline
\end{tabular}

Dari hasil penelitian ini memperlihatkan bahwa kualitas buah tomat terbaik cenderung dilihat pada perlakuan lama pencelupan 90 detik, walaupun tidak berbeda nyata dengan perlakuan lama pencelupan 30 dan 60 detik. Hal ini dikarenakan semakin lama pencelupan lalu lapisan coating yang terbentuk akan semakin tebal hingga dapat mengurangi proses metabolisme pada buah tomat. Budi dan Bambang (1995) mengemukakan bahwa metabolisme bisa dihambat dengan susunan lilin alami dengan memanfaatkan ekstrak aloe vera. Pelapisan bisa memperlambat degradasi kandungan warna selam penyimpanan. Tekstur buah tomat ialah kelembaban kulit pada buah tersebut yang bisa dilindungi dengan baik menggunakan lama pencelupan. Lama perendaman kedalam gel lidah buaya bisa memperkecil kerusakan pada buah tomat yang disebabkan oleh 
degradasi dinding sel (Sartika et al., 2015). Hasil penelitian Priyanto (1998) menyatakan bahwa gel aloe vera yang melapisi pepaya dapat memperlambat degradasi penyusun dinding sel karena dilindungi oleh susunan aloe vera. Pada hasil penelitian Hasanah (2009) menyatakan bahwa perlakuan lama pencelupan paprika selama 60 detik kedalam gel lidah buaya dengan konsentrasi CMC 1\% memiliki penurunan susut bobot dan nilai kekerasan terkecil dan dapat menambah masa simpan sampai 20 hari.

\section{KESIMPULAN DAN SARAN}

Perlakuan konsentrasi gel lidah buaya berdampak nyata pada uji organoleptik warna, serta berdampak tidak nyata pada susut bobot, kadar air, vitamin C, warna pada nilai L (kecerahan), a (merah), b (kuning), uji organoleptik tesktur, aroma dan rasa. Konsentrasi gel lidah buaya terbaik untuk meningkatkan kualitas buah toma terdapat pada perlakuan $45 \%$. Lama pencelupan berdampak tidak nyata terhadap susut bobot, kadar air, vitamin $\mathrm{C}$, warna pada nilai $\mathrm{L}$ (kecerahan), a (merah), b (kuning) dan uji organolpetik warna, tekstur, aroma dan rasa. Lama pencelupan ke dalam gel lidah buaya terbaik cenderung dijumpai pada perlakuan 90 detik walaupun tidak berbeda nyata dengan perlakuan 30 dan 60 detik . Terdapat interaksi yang tidak nyata antara perlakuan konsentrasi gel lidah buaya dan lama pencelupan terhadap kualitas buah tomat.

\section{DAFTAR PUSTAKA}

Badan Pusat Statistik 2019. Produktivitas Tomat Indoneisa 2016-2017. Badan Pusat Statistik. Jakarta.

Budi, B. S. dan S.P Bambang. 1995. Fisiologis dan Teknologi Pasca Panen Tanaman Hortikultura. Eastern University Project Indonesia Australia AusAID.

Budiman. 2011. Aplikasi pati singkong sebagai bahan baku edible coating untuk memperpanjang umur simpan pisang cavendish (Musa cavendidh). Skripsi Fakultas Teknologi Pertanian Institut Pertanian Bogor. Bogor

Drakel, A. 2011. Kajian usaha tani tanaman tomat terhadap produksi dan pendapatan petani (Studi Kasus di Desa Golago Kusuma, Kecamatan Jailolo Timur, Kabupaten Halmahera Barat). Jurnal Ilmiah agribisnis dan Perikanan (agrikan UMMU- Ternate). 4(2):31-35.

Garcia, M.A., M. Ventosa, R. Draz, S. Falco and A. Casariego. 2013. Effect of aloe vera coating on postharvest quality of tomato fruits. 69(2):117-126.

Hasanah, U. 2009. Pemanfaatan Gel Lidah Buaya sebagai Edible Coating untuk Memperpanjang Umur Simpan Paprika (Capsicum annum Varietas Sunny). Skripsi. Institut Pertanian Bogor. Bogor.

Marwina, R., R. Agustina dan B.S. Putra. 2016. Perubahan mutu tomat (Lycopersicum esculentum Mill.) dengan variasi konsentrasi pelapisan gel lidah buaya (Aloe vera L.) dan suhu penyimpanan. Jurnal Ilmiah Mahasiswa Pertanian Unsyiah. 1(1):985-994.

Mateljen, G., 2007, The Word Healthist Food, http//www whfoods.org/whffoods Tomatoes. Tanggal akses 3 januari 2011. 
Sartika, R. Hayati dan E. Kesumawati. 2015. Kajian Kandungan Vitamin C dan Organoleptik dengan Konsentrasi dan Lama Perendaman Ekstrak Lidah Buaya (Aloe vera L.) terhadap buah tomat (Lycopersicum esculentum Mill). Prosiding Seminar Nasional Biotik. Hal: 257-265.

Subagio, F. 2017. Penggunaan Edible Coating Gel Lidah Buaya terhadap Perubahan Warna, Kekerasan dan Organoleptik Buah Tomat Selama Penyimpanan. Skripsi. Fakultas Teknologi Pertanian. Universitas Katolik Widya Mandala. Surabaya.

Sulistyowati, A., E. Sedyadi dan S.Y. Probawati. 2019. Pengaruh penambahan ekstrak jahe (Zingiber officinale) sebagai antioksidan pada Edible film pati ganyong (Canna edulis) dan lidah buaya (Aloe vera L.) terhadap masa simpan buah tomat (Lycopersicum esculentum). Analit. 4(1):1-11.

Toro, O. R., S.C. Bigliardi, J. Rosello, P. Santamarina and A. Chiralt. 2017. Antifungal starch-based edible film containing Aloe vera. J. Food Hydrocolloids. 72:1-10

Pantastico. 2003. Manajemen dan Budidaya Tomat. Agromedia Pustaka. Jakarta.

Priyanto, G. 1988. Teknik Pengawetan Pangan. PAU Pangan Gizi. Universitas Gadjah Mada. Yogyakarta. 244 halaman

Yudiana. 2013. Penggunaan Gel Lidah Buaya dan Suhu Rendah terhadap Umur Simpan Buah Anggur (Vitis vinifera L.). Skripsi. Fakultas Pertanian. Universitas Syiah Kuala. Banda Aceh. 